\title{
The Sage and the Demos: The Intellectual within Athenian Cultural and Social Landscape of the Fifth and Fourth Centuries BCE
}

\author{
Roman V. Svetlov and Vasiliy A. Rabosh* \\ The Herzen State Pedagogical University of Russia \\ 48 Moyka Embankment, St. Petersburg, 191186, Russia
}

Received 30.05.2019, received in revised form 20.06.2019, accepted 04.07.2019

The Athens of the Classical period saw the emergence of a new social group - the intellectuals. This article looks into their socialisation process, focusing on a part of Plato's Apology (21a-22e). In it, Socrates lists three groups of Athenians that compete with the intellectuals in shaping young minds: politicians, poets and artisans. It is these groups that ended up bringing charges against Socrates. The fact that Socrates does not include farmers into his list of the essential estates is analysed separately. The passages discussed here are quite representative for the purposes of historical sociology of intellectual culture, illuminating the way the intellectual conceptualised the role and the place of his social group within the larger polis while entangled in a social conflict of Classical Athens. An intellectual is both unnecessary and inconceivable in the context of the utopian Age of Cronus (Statesman) or the rustic first city (Republic). He does not belong in the classical city either, but can only be found there. The awareness of the conflict inherent in the intellectual's existence in Athens and the description thereof is one of the manifestations of Plato's dialectics.

Keywords: Socrates, the intellectual in Antiquity, social and cultural conflict in Athens.

The reported study was funded by RFBR according to the research project № 18-00-00727(1806-00628).

Research area: culturology.

Citation: Svetlov, R.V., Rabosh, V.A. (2019). The sage and the demos: the intellectual within Athenian cultural and social landscape of the fifth and fourth centuries BCE. J. Sib. Fed. Univ. Humanit. soc. sci., 12(7), 1335-1343. DOI: 10.17516/1997-1370-0452.

Ancient Athens was a city unlike any other, defined by its peculiar political psychology. However, it so happened that Athens is the only specimen of classical culture available to modern scholars, since it is mostly Athenian literature, including

(C) Siberian Federal University. All rights reserved

* Corresponding author E-mail address: spatha@mail.ru

ORCID: 0000-0001-7767-1441 (Svetlov); 0000-0002-7241-6748 (Rabosh)

This work is licensed under a Creative Commons Attribution-NonCommercial 4.0 International License (CC BY-NC 4.0). 
both dramatic poetry, history and philosophy, that survived from the classical period of the fifth and fourth centuries BCE and has been universally treasured ever since.

Philosophers and scholars, wherever they hailed from, mostly resided in Athens; we only hear about their activities beyond Attica in their own - often boastful accounts of their scholarly exploits. Hippias of Elis, for instance, recounts his successes in other cities to Socrates: he carried out foreign policy assignments and even taught in Sparta, instructing Lacedaemonians in genealogies, the founding of cities, etc. This was outside of Athens, though, and everything we know about sophists' real accomplishments and recognition abroad (Gorgias's school in Larissa, his speech in Olympia, Prodicus's lectures in Thebes and Sparta) has no value within Athens city walls. Here, their wisdom is — often cruelly - tested; this is what Plato's Socrates does. The barefoot sage who knew that he knew nothing could easily demonstrate that the wisdom of Hippias, Gorgias and Protagoras was fake, not a true wisdom.

The reality, of course, was not as clear-cut. Sophists did enjoy relative success as teachers and had both wealthy patrons and true fans like the unnamed friend of Socrates from Protagoras. However, there were also many who were critical of their "wisdom", represented by the comedians who tended to make the babbling philosopher the butt of their jokes on one end of the spectrum, and Socrates with his decisively elenctical attitude on the other. Another point we have to bear in mind is that while the sophists worked on their Hellenic enlightenment in Athens, the city also saw the adoption of the decree ( $\psi \eta \dot{\varphi} \varphi ı \mu \alpha$, literally "decision") of Diopeithes (434 BCE) that allowed for prosecution of "those who fail to respect things divine." This decree was used to prosecute Anaxagoras and Protagoras, Aspasia and Diagoras. It subsequently became part of the body of Athenian law during the process of law (including sacred law) codification after the Peloponnesian War under the archonship of Eucleides (Nikitiiuk, 2018: 73). One of the charges against Socrates also had a religious character, and the defense of Socrates against it has recently attracted the special attention of researchers (Samaras, 2007).

One should not assume, though, that the trend towards more complex regulations of religious affairs and harsher punishments of religious crimes only applied to the intellectuals. It also targeted those who tried to introduce any kinds of innovations, those criminally negligent in their duties before gods, those who overstepped their authority or misinterpreted religious actions, as well as the freethinkers like Diagoras and Alcibiades (the latter was prosecuted together with a group of friends for profaning 
the Eleusinian Mysteries in $415 \mathrm{BCE})$. But what we are interested in are intellectuals, or, more precisely, their incorporation into the Athenian society.

Although the Greek world saw the first sages and proto-scholars two centuries earlier, all of the cases where they clashed with their social surroundings were either made up during the Hellenic period (the attacks on the first Pythagorean community in Croton, the Pythagoras's proud refusal to work with Polycrates) or were of a totally different nature (Heraclitus and the citizens of Ephesus). What we see in Athens, though, is a true social conflict, a conflict that is gradually recognized as such by the opposite parties that are starting to appeal to tradition, law, religion and the new and established horizons of knowledge. It is in this city that intellectuals were for the first time seen as a separate social group. And, although they enjoyed support of a part of the ruling elite (at least while Athens were led by Pericles, who was interested in new teaching practices and knowledge) they were widely mistrusted and disliked almost from the outset. While new intellectuals were quite a heterogeneous group and included Meton the astronomer, Hippodamus the utopian urban planner, Pythagoreans with their peculiar anthroposophic ethics, Sophists, Socrates, etc., the public believed they were cast in the same - negative - mold embodied by an Athenian comedy character. That character had a loose tongue, led parasitic existence, was suspiciously feminine and emphatically impious. If he did seem ascetic, that meant he was either vulgar or hypocritical. Simply put, their daimon was evil, and their lot unenviable (Svetlov, 2017).

Association with this comedic character was a part of the price intellectuals paid for living in Athens. Contrary to the naive idea of Athens as a shining city upon a hill, filled with art, scientific and philosophical innovations, the realities of the fifth and fourth centuries BCE were much more sombre. Athenians en masse had grown to be quite apprehensive of or even negative towards the intellectuals who promoted projects or ideas that differed from the traditional and universally accepted ones. The reasons for this attitude were quite complex. Although Athenian society does indeed seem to be the most progressive in the ancient world judging by the modern standards, there were other factors, including the sometimes excessive urge for social cohesion, the totality of civic bonds, as well as the city's deliberate fight for leadership in the fifth century, that prompted Athenians to be apprehensive towards anything new, anything that defies the entrenched patterns of social and religious (intrinsically social) behaviour. Contrary to Pericles's famous words in the burial speech, Athenians generally did not tend to "cultivate the mind" (Thucid. Hist.: II. 
40) beyond what was deemed acceptable and proper, i. e. what was approved by both written and unwritten rules.

Let us now look into an intellectuals' apology, a fragment from Socrates's court speech. In our opinion, it is a clear example of the way this new man self-identifies within the Athenian society, how he maps the society and which social groups are important to him. Finally, this segment also outlines the sources of competition, both social and mental, that this intellectual faces.

Socrates explained his behaviour (his questions to Athenian citizens) saying that he wanted to investigate whether Delphian oracle was right in announcing that there was no one wiser than he (Plato. Apol.: 21a). Apparently, he just wanted to test public men's wisdom but learned that they in fact did not know anything at all. The wisdom of poets and hand-workers turned out to be as fake (Plato. Apol.: 22c-e). Socrates's questions moderate the claims of various Athenian groups to knowledge (King, 2008).

Thus, Socrates lists three social groups that he wanted to test following the Delphian oracle's statement. The first one is orators/politicians; rhetoric in Socrates/ Plato's views is inextricably linked with politics, it gives rise to statesmanlike charlatans (see Statesman: 291a-c). The second group is poets. They are also privy to power; not necessarily as thought leaders, but as those who guide younger minds. Plato extensively criticizes this facet of poetic art in the Republic II-IV, where he denounces Athenian paideia that necessarily included epic — and not just epic — poets. The third group - artisans — Plato is generally quite ambivalent about. It is manual labour and is, what is more, connected to bourgeois enterprise, so he is not particularly fascinated with it. On the other hand, the Republic does take place in the home of Cephalus, a metic workshop owner and entrepreneur. Additionally, the demiurge is described as an artisan in Timaeus. The artisans of the Apology, though, are clearly the city-dwellers that possess both authority and social weight (Anytos speaks on their behalf) and, therefore, power.

The fact that Socrates failed to list farmers is going to be discussed later. Let us now mention, though, that this grouping is not based on lineage, property ownership (e. g. land, workshops, ships, etc.), census or even full citizen rights or lack thereof. The only thing taken into account is one's profession, i. e. what one does within the polis as a whole.

Why are these groups criticized? They are devoid of knowledge and wisdom. Essentially, the dispute between Socrates and the judges is about the right to be called an expert. In an attempt to explain to Socrates who makes Athenian young men better, 
Meletus gives a successive mention of laws, judges, the councilmen (the Boule), and, finally, the Assembly (Plato Apol.: 24d-25a). Holding imperium (a parallel drawn with Rome) gives access to authority and imperative. Hence, experts are those citizens of Athens who fulfill their political duty. This is the opinion held by Meletus and, apparently, most judges who passed a judgment on Socrates.

However, Socrates proves that none of them are experts; neither orators, nor poets, nor craftsmen, whose representatives sit in courts. In fact, his experience of verifying what the oracle said about the wisest man in Athens confirms the god in Delph was right. Education is an effort based on something drastically different from the "wisdom" of an orator, a poet or a craftsman. You may remember that, according to Socrates, an orator is a simulacrum of a wise man. The poets are mere intermediaries, town criers whose mission is to capture poetic inspiration without even questioning its nature. The wisdom of craftsmen is in their labor and their manual skills. At best all they can say is, "Do as I do!"

The thrust of Socrates's claim is that the Athenian society does not have an expert in education, i. e. an intellectual, as the only professional able to see that every citizen is at his/her "post/station" on a par with an experienced commander reviewing troops under his supervision (Goldman, 2009: 462-467). Socrates was totally against rationality so much valued in Athens of that time. The classic example is Nicias, a politician and a general, with his passion for prophecy. In Ancient literature Nicias is portrayed as a rather conventional, cautious politician. According to Plutarch, Nicias consulted a diviner about the commonwealth and his own private affairs (Plutarch. Nikias: 3.3). This is confirmed in Laches, a dialogue written by Plato (195e). For a long time, Nicias knew no defeat due to his generalship based on forward-looking caution and superstitions.

However, his success as a politician came to an end during the Sicilian expedition. Even though Nicias doubted the mission would be effective and was open about it, he was appointed as commander and joined the expedition. They scored a number of early success but failed to sustain it. A reinforcing armada from Athens did not turn the tide. In the end of the Sicilian expedition Nicias fell ill, most likely with a kidney stone disease. An attempt to retreat to safety failed when the lunar eclipse during the night of 27 August 413 B.C. was taken by most of the Athenians and the commanders as a very bad omen. The consultations with divine powers did not help. As a result, the army was in total disarray and Nicias was taken captive and executed (See: Thuc. Hist.: VII. 42.3; VII. 71; VII. 73; Plutarch. Nikias: XXI, XXIII-XXIV). 
However, this practical proof that the old rationality was outdated and ineffective did not convince the Athenians. On the contrary, they strongly opposed this new group that thought outside the box and wanted to climb up the social ladder, i. e. to gain authority. Education is, after all, political and represents a kind of authority. In the Republic Plato makes a direct mention of an occupation meant for intellectuals - to be teachers/rulers - avoiding the path of rhetoricians, poets or craftsmen. Therefore, it is no surprise that intellectuals induced jealousy in those who held authority, i. e. the demos from a formal legal perspective and "advocacy groups" from an informal perspective.

The Apology's critical review of the Athenian society anticipates Plato's occupationbased approach to describing the society in Book 2 of the Republic. In light of this, the lumpen intellectual intangibility of Socrates becomes more clear. We mean to say that Socrates does not quite fit any common social or professional group. Socrates is neither a professional orator, nor is he a craftsman: he gave up sculpting when he was still young. He is not a farmer, at least, he is never featured with a plough or doing household chores. Although he is a courageous and skilful soldier, soldiery is rather his duty, than a profession. If we look at Plato's or Xenophon's writings, we find that Socrates had all sorts of acquaintances - metics, full-fledges citizens and visitors to the city. Many of his friends came from an aristocratic background. Like them, Socrates opposes the type of democracy established in Athens of that time. Not a tragedian himself, Socrates is friends with Agathon and Euripides, and sometimes enjoys a glass with Aristophanes. I may safely assume that the hypothesis about Socrates's aristocratic ancestry that could shed some light on this situation is superfluous. Socrates, or at least his image created by Plato, simply does not belong to any of the "professional" groups he describes in the Apology. Hence, the pool of his friends, confidants or drinking companions may include representatives from any common strata of the Athenian society. This is the destiny of an intellectual of the new, rational type whose social position is still being shaped, and which has not yet come to the pessimistic conclusion that philosophy and politics little compatible with each other (Ward, 2009).

A question begs itself: why did not Socrates interrogate the farmers? There are three possible answers to this question. First, Plato underscores how much Athens has lost touch with the land, ancient Athens, peasantry, and the Athenians who defeated the Persians in the battle of Marathon. It is commonly known that Plato was an advocate of an agricultural polis and classical hoplitic land battles. Now there are no farmers among judges. They got urbanized in the wake of fashion, if not in essence. 
Second, which is similar to the first, deals precisely with fashion. Despite the myths about earthborn men and the emergence of agriculture in Eleuseus as Demetra's gift, countrymen were ridiculed in urban Athenian culture, especially in comedies and satyr plays.

For this reason, at the time of Socrates and Plato an Athenian perceives him/herself as a citizen with the knowledge of city manners and its quality of life. Let us recall that in Book 2 of the Republic, Socrates's interlocutors call his "true" rustic polis "a city of pigs" (372d). They make him speak about the society which has swollen because of its needs and, hence, professions which satisfy them, i. e. about the city per se. Therefore, if there are any farmers, they do not perceive themselves as farmers and hide their true spirit.

Third, farmers might be beyond Socrate's reach because he focuses on the bucolic times in the history of humanity which, due to Dicaearchus, are known as the Golden Age. By way of reminder, it was due to the ancient, rustic, powerful Athens that the army of Atlantis was smashed (Timaeus: 25a-d). The Statesman describes the reign of Cronos, when the Earth rotated in the reverse direction, as the days of simple life with the abundance of fruits it generously provided. Finally, to repeat what we said before, the rustic "city of pigs" from the Republic was nothing but a "true city" for Socrates.

Neither of the cases has any room for an intellectual. The reign of Cronos is marked by direct communication between demons/gods and people. There is no need for a philosopher as an intermediary between mortal humans and gods. Philosophers are also useless in the agricultural world of the Republica or where people have lived a righteous life from birth and experienced no evil, i. e. seductions of the city life. A philosopher is out of place (atopic) in urban environment. Here he is always at risk of being put to death by a crowd who will consider his eyes to be full of darkness (Republica: II, 517a).

Despite the risk of the profession, despite the irrelevance, the city is the only place for a philosopher to fulfill his calling and speak to his audience. Therefore, on the one hand, Plato's dialogues often contain post factum prophecies about Socrates's destiny. On the other hand, Socrates addresses Phaedrus in the namesake dialogue, "You see, I am fond of learning. Now the country places and the trees won't teach me anything, and the people in the city do" (Phaedr.: 230d). This controversy adds a note of tragedy to Plato's writings and, according to some modern scholars, even to the "discourse of truth". The latter is a structural and discursive practice rather than emotionality or affection (Glukhov, 2018). 
According to historical sociology of intellectual culture, Plato's writings are a valuable example of introspection of an Athenian intellectual of the classic era with the focus on his calling and his place in the social body of the polis. It should be noted, that the understanding and the description of this place is highly controversial which fits in with Plato's dialectic. It juxtaposes the opposites in their reality and differences as two non-abstract, material moments of the whole. However, this is absolutely beyond the scope of our research.

\section{References}

Glukhov, A. (2018). Platon, istina i tragicheskaia peremena [Plato, the truth, and tragic change]. In Sbornik materialov XXVI nauchnǒ konferentsii: "Platonovskoe nasledie $v$ istoricheskŏ retrospektive: intellektual'nye transformatsii $i$ novye issledovatel'skie strategii» [The proceedings of the $26^{\text {th }}$ scientific conference: "Platonic heritage in Historical Retrospective: Intellectual Transformations and New Research Strategies"']. SPb, 363-371.

Goldman, H. (2009). Traditional Forms of Wisdom and Politics in Plato's “Apology". In The Classical Quarterly, New Series, 59 (2) (Dec., 2009), 444-467.

King, Chr. (2008). Wisdom, moderation, and elenchus in Plato's "Apology". In Metaphilosophy, 39 (3) (July 2008), 345-362.

Nikitiiuk, E. (2018). Afinskie nechestivtsy. Protsessy po obvineniiu v religioznom nechestii v Afinakh v kontse Vv. do n. e. [Athenian impious man. Processes on charges in religious impiety in Athens in the end of $5^{\text {th }} B C$.]. SPb: Gumanitarnaiia akademiia, $447 \mathrm{p}$.

Olding, G.G. (2003). Anti-intellectualism in Classical Athens. University of Adelaide. 404 p.

Samaras, Th. (2007). Who believes in Socrates' innocence? The religious charges against Socrates and the intended audience of Plato's apology. In Polis, 24 (1), 1-1.

Svetlov, R. (2017). Legko li (bylo) byt' «sokratikom»? Pristrastnyı̆ vzgliad komedii na Xèrefonta iz Sfetta [Was It Easy to Be a Socratic? A Biased View of Athenian Comedy on Chaerephon of Sphettus]. In Platonovskie issledovaniia [Platonic Investigations], 7, 2 (7), 84-96.

Ward, L. (2009). The Relation between Politics and Philosophy in Plato's Apology of Socrates. In International Philosophical Quarterly, 49 (4), 501-519. 


\title{
Мудрец и демос: интеллектуал в культурном \\ и социальном горизонте Афин V-IV вв. до н. э.
}

\author{
Р.В. Светлов, В.А. Рабош \\ Российский государственный педагогический \\ университет им. А. И. Гериена \\ Россия, 191186, Санкт-Петербург, \\ набережная реки Мойки, 48
}

$\overline{\text { Статья имеет своей иелью изучить процесс социилизаџии новой общественной про- }}$ слойки, прослойки интеллектуалов, в классических Афинах. Центральный текст, ставший предметом исследования, - фрагмент из платоновской "Апологии Сократа» 21a-е, где Сократ перечисляет те группы афинских граждан, которые стали конкурентами интеллектуалов в вопросе о воспитании: риторов-политиков, поэтов и ремесленников. Именно эти группы и представили обвинения против Сократа. Особой темой для анализа стало отсутствие земледельцев в списке актуальных для Сократа «сословий». Фрагмент показателен с точки зрения исследования исторической соииологии интеллектуальной культуры того, как интеллектуал, оказавиийся в классических Афинах в конфликтном поле, осмысливал предназначение и место своей социиальной группь в политическом теле полиса. Интеллектуал не нужен и не возможен в условиях утопического «века Кроноса» («Политик») и буколического «первого полиса» («Государство»). Он атопичен и в городе, но лишь город является местом его существования. Осознание и описание конфликтности статуса интеллектуала в Афинах служит одним из проявлений платоновского типа диалектики.

Ключевые слова: Сократ, античный интеллектуал, сочииальный конфликт в Афинах.

Исследование выполнено при финансовой поддержке РФФИ в рамках научного проекта № 18-00-00727(18-06-00628).

Научная специиальность: 24.00.00 - культурология. 